\title{
Evaluating Visual Quality of Natural Landscapes to Achieve Sustainable Development: A Case Study of Margoon Waterfall Protected Area, Iran
}

\author{
Ferial Ahmadi ${ }^{\star}$, Mohammadreza Bemanian and Mojtaba Ansari
}

Department of Architecture, Faculty of Art and Architecture, Tarbiat Modares University, Iran

\begin{tabular}{lll}
\hline \multicolumn{1}{c}{ Abstract } & Article Information \\
\hline Margoon waterfall protected area due to its ecological and environmental values and & Article History: \\
capitals can attract native and exotic tourists but incompatible development plan to the & Received : 13-06-2014 \\
natural capitals of this site causes many problems. Therefore, the current research was & Revised $: 19-09-2014$ \\
formed to present sustainable strategies in Margoon protected area. In the current & Accepted : 28-09-2014 \\
\cline { 2 - 2 } research, survey method has applied. To find reasons of the tourists and native & Keywords: \\
communities' presentence, a questionnaire is prepared in two parts and distributed to 100 & Visual analysis \\
tourists. To achieve the problems of development plan, 14 points are choosing in the case & Sustainable design \\
study (Margoon waterfall protected area). These points located in privileged, ordinary, and & Natural landscape \\
\cline { 2 - 2 } poor landscapes in development plan. To analyze the visual evaluation of these points, & Ferresponding Author: \\
GIS software is used. & E-madi \\
& Copyright@2014 STAR Journal. All Rights Reserved. & ferial_ahmadi@yahoo.com \\
\hline
\end{tabular}

\section{INTRODUCTION}

"Landscape is that part of the environment in which we live and we realize by our senses. We can't escape from it or consider it as an optional subject which is either extra or special for spending our leisure time" (Bell, 2003). In fact, landscape is a "relatively bounded area or unit. Its recognition depends on human perception (Selmun, 2008). Therefore, landscape can be defined as 'an area, as perceived by people, whose character is the result of the action and interaction of natural and/or human factors' (Council of Europe, 2000).

It is obvious that people's degree of perception of the environment and surrounding sceneries depends on their mental readiness and abilities as well as environmental capacity and conditions that include layers of form, operation, and meaning. Therefore, "landscape has a complicated layer and vague meaning that would never be simplified or linear. Everybody knows that since long time ago "landscapes confirm or deny previous memories of the past. A social and cultural past even if it is beyond individuals' experiences records human memories and memory is the basis of identity" (Spirn, 2000). Forman and Godron (1986) defined landscape as a heterogeneous land area composed of a cluster of interacting ecosystems that is repeated in similar form throughout. Turner et al (2002) define landscape as an area that is spatially heterogeneous in at least one factor of interest. Landscapes are "open" systems; energy, materials, and organisms move into and out of the landscape (McGarigal, 2002).

Some researchers believe that the natural landscape is a pristine landscape and the other say the natural landscapes are related to human interaction and they believe that landscape require continuous human interaction and intervention (Farina, 2007). Therefore, they classify landscape in to three types: 1) natural landscape 2) man- made landscape and 3) composition landscape.

Unfortunately; nowadays, people have destroyed their relationships with landscape by violating the environment and their surrounding natural settings and consequently have lost their identities. Therefore, the current research formed to analyze virtual quality of tourism development plan in Margoon waterfall protected area and present sustainable tourism strategies.

\section{MATERIAL AND METHODS}

We use survey method in the current research with some library research. At first, we emphasize on the necessity of awareness of landscape designer as the leaders in design and intervention of landscape. Therefore, necessary definitions such as landscape, natural landscape scrutinized. Then we prepare a questionnaire in two parts and distribute it to 100 native and exotic tourist who attended in Margoon waterfall protected area to find reasons of the tourists and native communities' presentence in this site and their needs. The first part of the questionnaire evaluate descriptive characteristic of participants and the second parts assess their needs. In addition to evaluate visual angels in development design, we recognize 14 points in Margoon site and use linear angles to achieve how the view of this point to Margoon waterfall. It should mention that we use GIS and SPSS software to analyze maps and questionnaire's data. In addition, to analyze visual angles, 
Ferial Ahmadi et al.,

we use the method that was presented in year 2011 by Makhdoum.

The concept of "sustainability implies an efficient and precise balance between today's needs and tomorrow's, also between personal motives and public measurements in greed and people's social sympathy and kindness" (Perank and Mahboobolhagh, 2001). But the common point in all definitions of sustainability and sustainable development is "protecting the environment as a bed for development which becomes possible by the four basic pillars of sustainable development which are economical, social, cultural and environmental developments" (Dicastri, 1996). Overall Carmona introduces ten factors: self-reliance, environment improvement, decreasing pollution, centralization, respecting human needs, flexibility, resources usefulness, variety and decision, distinction and supervision. In fact, it seems that, supervision, resources usefulness and self- reliance are defined in the economical framework of sustainability and variety and decision, human needs, flexibility, centralization, recognizing and distinguishing are part of the social framework of sustainability and environmental development, decrease in pollution actually make environmental sustainability possible. G. Thomson and F. Steiner as landscape design theorists, introduce basic principles of sustainable landscape based on principles of ecology and creativity. Therefore, by "entering the concepts of ecology and consistence in heading of
Sci. Technol. Arts Res. J., July-Sep 2014, 3(3): 161-165

objectives of landscape designers, besides promoting aesthetic satisfaction and advancement of healthy biologic, ecologic, and functional landscapes, their responsibility in regard to development of compatibility of developed and constructed environments in the landscape in the same direction with principles of consistence would be expanded" (Behbahani and Razi Moftakhar, 2005). Consequently, according to all the mentioned we have to try to protect all ecologic, social and economic values based on principles and criteria of consistence. Then we have to do our best in applying principles and criteria in compliance with exclusive values of bed in order to not only protect the development and promotion of social, economic, and environmental powers of these landscapes, but also to synchronize them with today needs" (Pourjafar Bemanian et al., 2011).

It should note that landscapes are recognized as appropriate realms for establishing desirable balance between environment, economy, and society. Therefore sustaining landscape summarized to interpretation of "for related elements in four parts of visual identity, environmental integrity, and socio-economic dynamic and temporal legibility. So to achieve sustainability of these elements the main capital of landscape (economic, social, cultural, and natural capitals) should be interpreted" (Ekins, Folke, and De Groot, 2003) to improve all features and values of the landscapes.

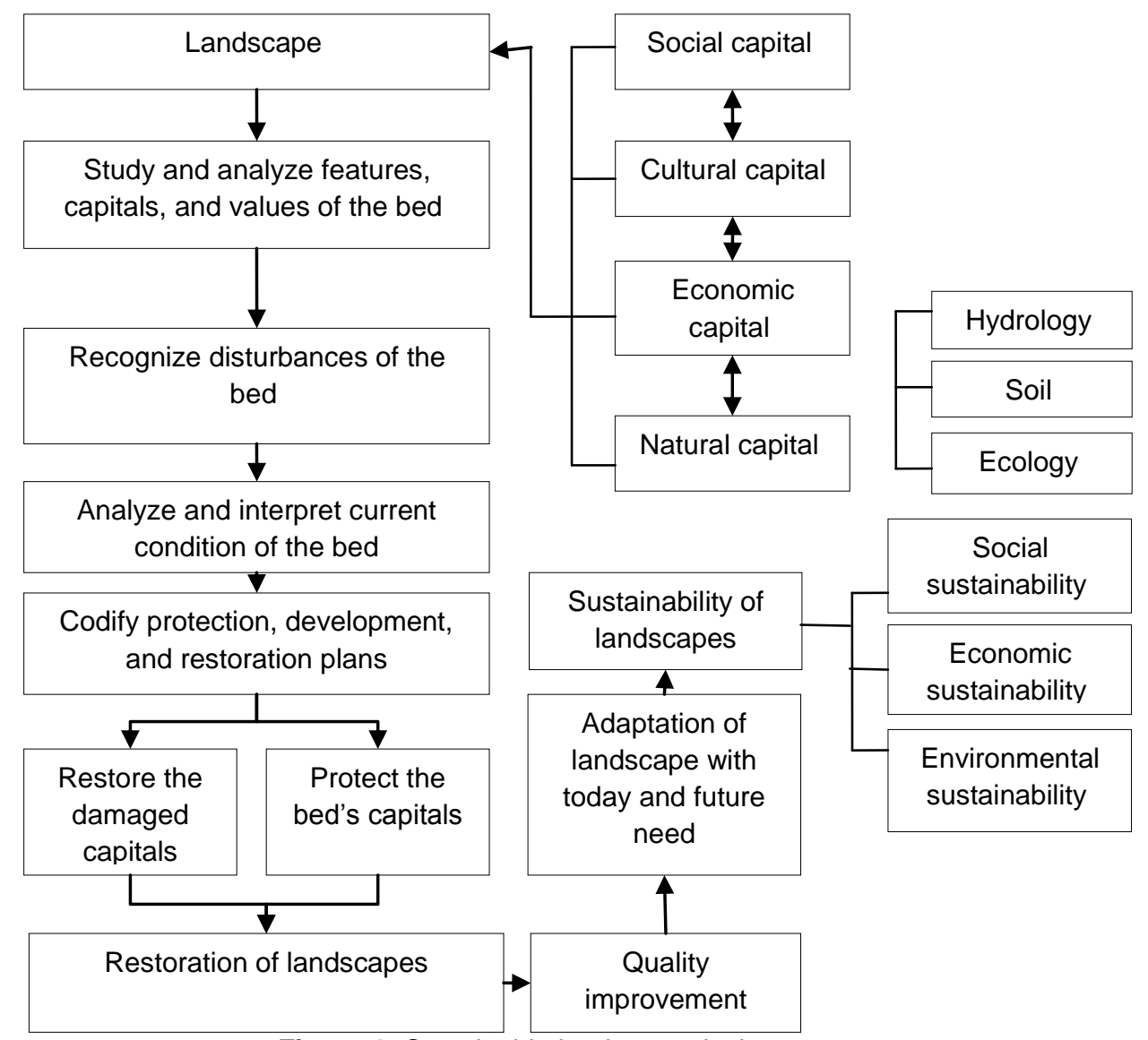

Figure 1: Sustainable landscape design process

\section{Case study}

Margoon waterfall protected area located in 53 degree and 54 minutes east longitude and 30 degrees 38 minutes north latitude. Water exit point located in an about 2200 meters above sea level. Plant communities and forest area is divided into three categories: 1) The pistachios and almonds society (located at 2800 meters), 2) Acorn society (located at 2500 meters), 3) riverside trees (poplar trees). 
Ferial Ahmadi et al.,
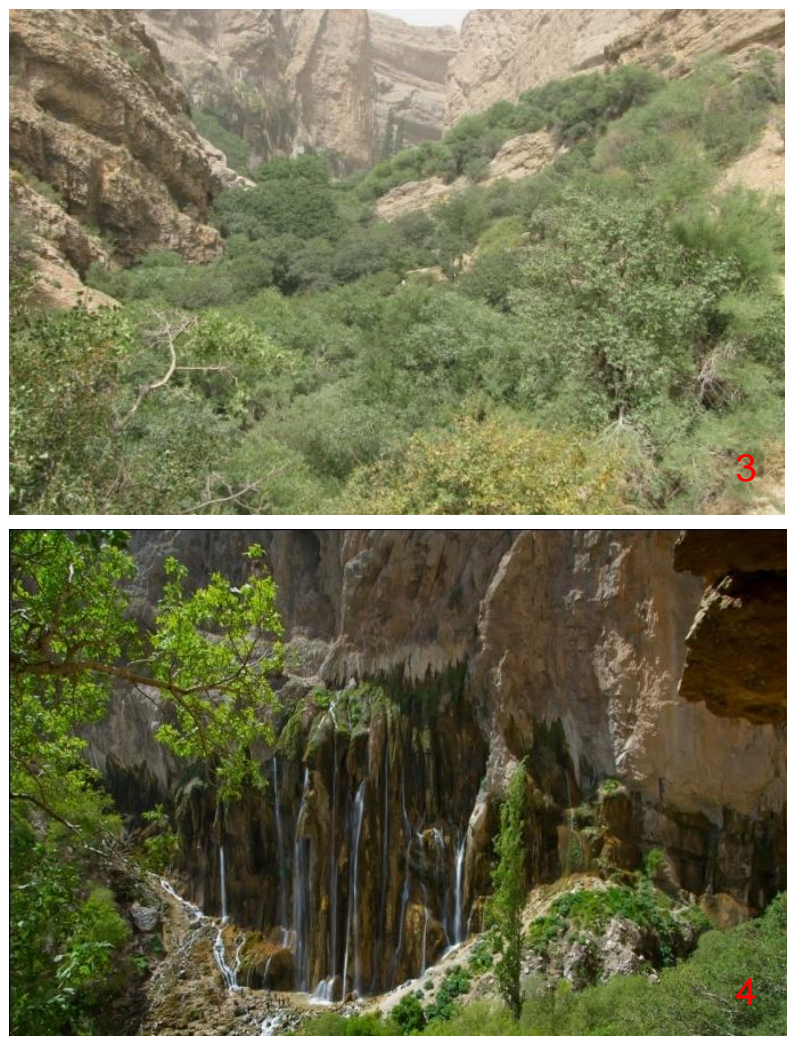

Figure 2 and 3: Plant communities of Margoon waterfall protected area

Animal society of Margoon waterfall protected area categorized into the following three categories: 1) birds include partridges, grouse, dull-yellow partridge, pigeon, dove, starlings, sparrows, hawks, and eagles, 2) aquaculture and fisheries, and 3) animals including sheep, ewe, goat, bear, otter, wolf, fox, jackal, hyena, rabbit and boar.

This area divided in tree ranges: 1-Margoon waterfall and riverside trees, 2- Zagros forests and 3-agricultural and horticultural lands. There are different slopes in theses ranges. For example in range 1, there are slopes greater than $70 \%$., and there are slopes $5 \%$ to $50 \%$ in range2. We analyzed overall height level of this site and classified them in eight categories by using GIS software (Table 1).

Table 1: Height level of Margoon waterfall protected area by using GIS software

\begin{tabular}{cccc}
\hline Surface & $\begin{array}{c}\text { Minimum } \\
\text { Height }\end{array}$ & $\begin{array}{c}\text { Maximum } \\
\text { Height }\end{array}$ & Area \\
\hline 1 & 2083,27 & 2203,65 & 1321086,33 \\
2 & 2203,65 & 2273,61 & 1257860,80 \\
3 & 2273,61 & 2320,16 & 1226409,65 \\
4 & 2320,16 & 2355,69 & 1102232,96 \\
5 & 2355,69 & 2384,70 & 1146371,74 \\
6 & 2384,70 & 2410,27 & 1054529,93 \\
7 & 2410,27 & 2449,10 & 1085046,29 \\
8 & 2449,10 & 2622,40 & 901430,95 \\
\hline
\end{tabular}

\section{RESULTS}

The most people of Margoon village farm. Some villagers are engaged in handicraft production. To achieve
Sci. Technol. Arts Res. J., July-Sep 2014, 3(3): 161-165

the levels of employment and recreational activities of the native communities, we prepare questionnaire and distribute it between 100 people. We use SPSS software to analyze descriptive characteristic of participants. In this research, $28.1 \%$ of the sample group has the educational degree e.g. BA, 30.9\% high school Diploma, 30.9\% under high school Diploma, $10.1 \%$ were MA or Ph.D. Also $73 \%$ of the respondents were married and $27 \%$ of them were single. In the same way, $25 \%$ of them were unemployed and only $75 \%$ had jobs. Figure 4 show the obtained results from the questionnaire about the activities of native communities in Margoon protected area.

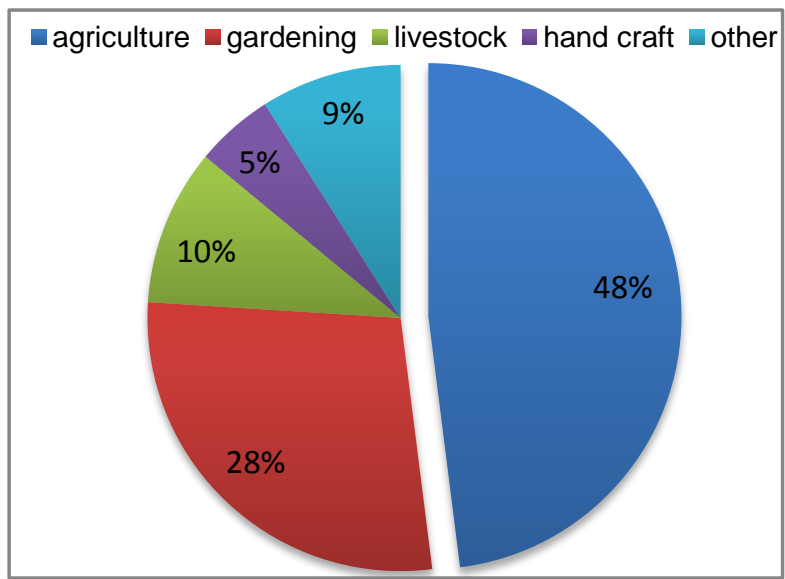

Figure 4: The activities of native communities

In addition to achieve the activities of tourist, we prepare another questionnaire and distribute it to 100 tourists. $40 \%$ of the sample group has the educational degree e.g. BA, $15 \%$ high school Diploma, $2 \%$ under high school Diploma, $43 \%$ were MA or Ph.D. Also $80 \%$ of the respondents were married and $20 \%$ of them were single. In the same way, $35 \%$ of them were unemployed and only $65 \%$ had jobs. The types of tourist's activities are shown in Figure 5.

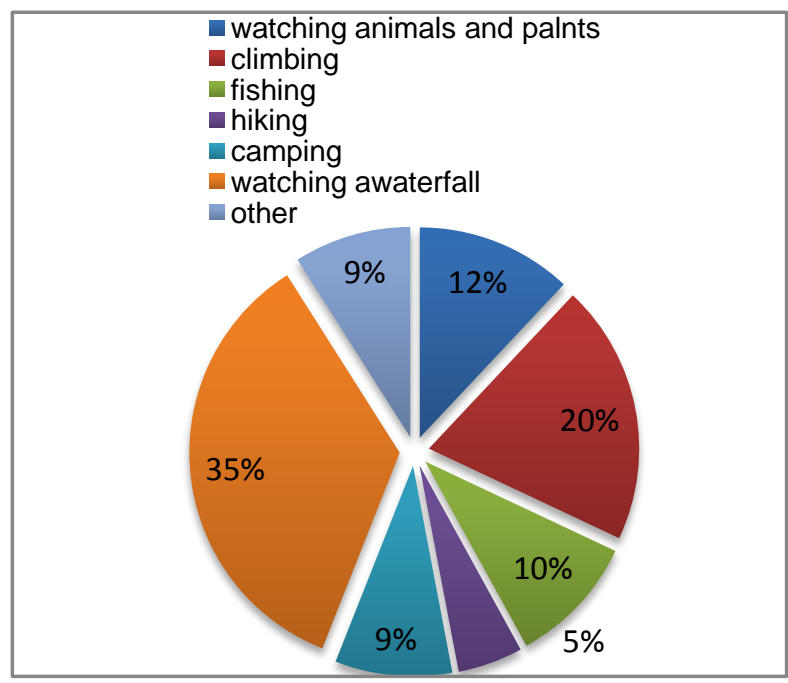

Figure 5: The activities of tourists

Survey analyses show the location of these activities in Margoon protected area. Some of these activities are done in places that have not been included in the development plan. Therefore, the main question is why the local communities and tourists not doing their activities in places that are marked in development plan. To 
Ferial Ahmadi et al.,

achieve the answer of the question, authors did interview with 50 tourists and local communities. The obtained result from interview indicates that in development plan, the visual needs of visitors don not considered. Therefore, to analyze the visual quality, we choose14 points in our case study (Margoon waterfall protected area). These points located in privileged, ordinary, and poor landscapes
Sci. Technol. Arts Res. J., July-Sep 2014, 3(3): 161-165

in development paln. Figure 6 shows the location of these points in Margoon area. Then the linear angles of view to Margoon waterfall from 14 points are analyzed by GIS software. It should mention that we use linear angle because focus center of Margoon site is Margoon waterfall (Figure 7 and 8).

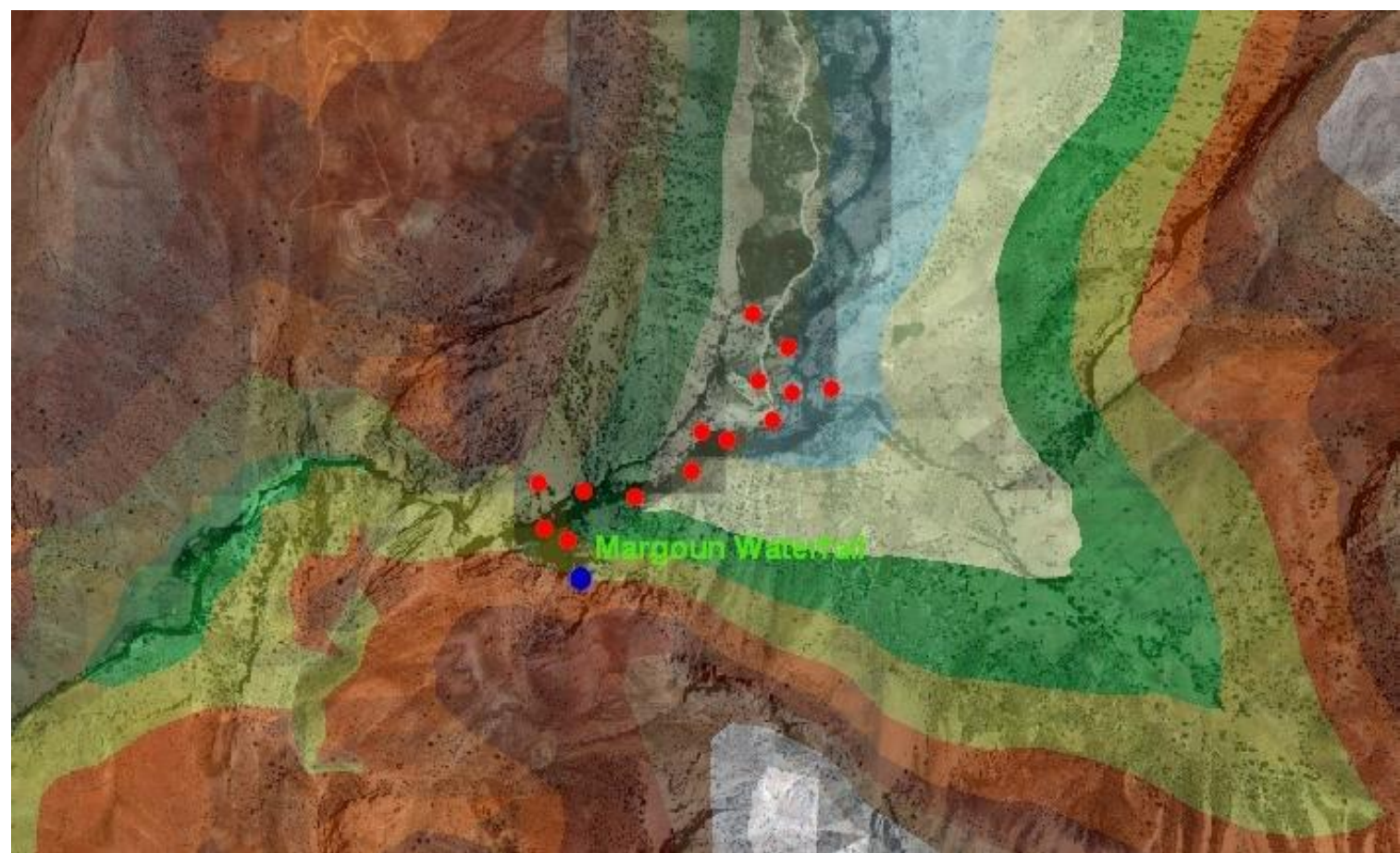

Figure 6: The location of points 1 to 14 in Margoon protected area
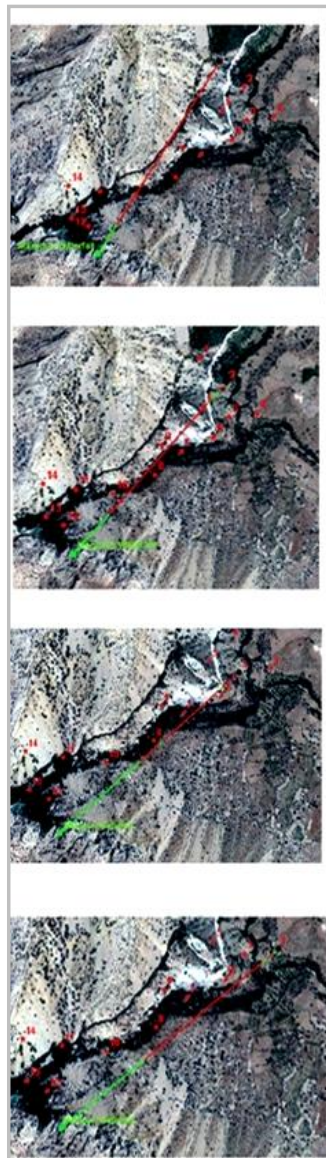
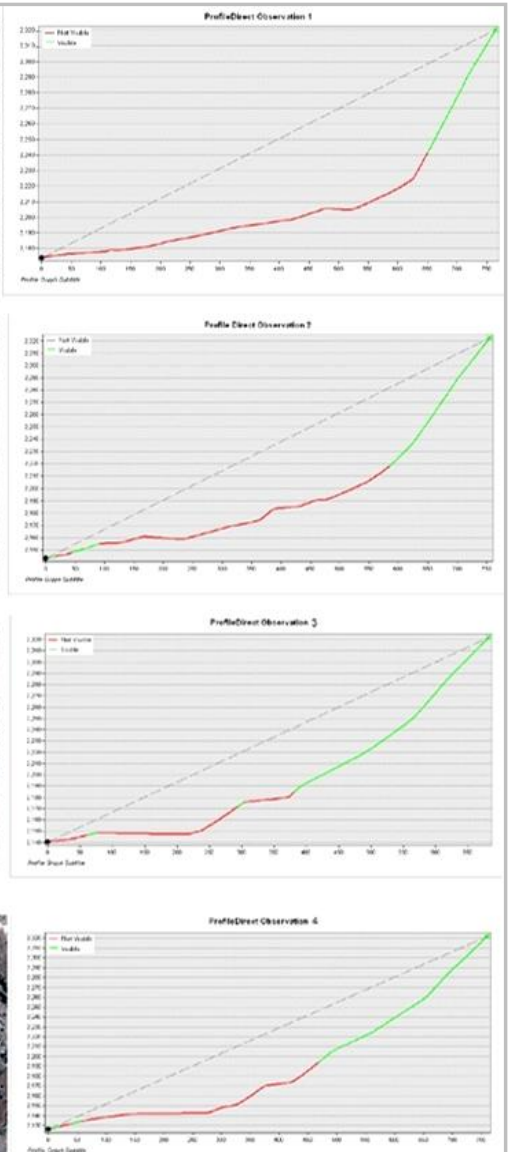
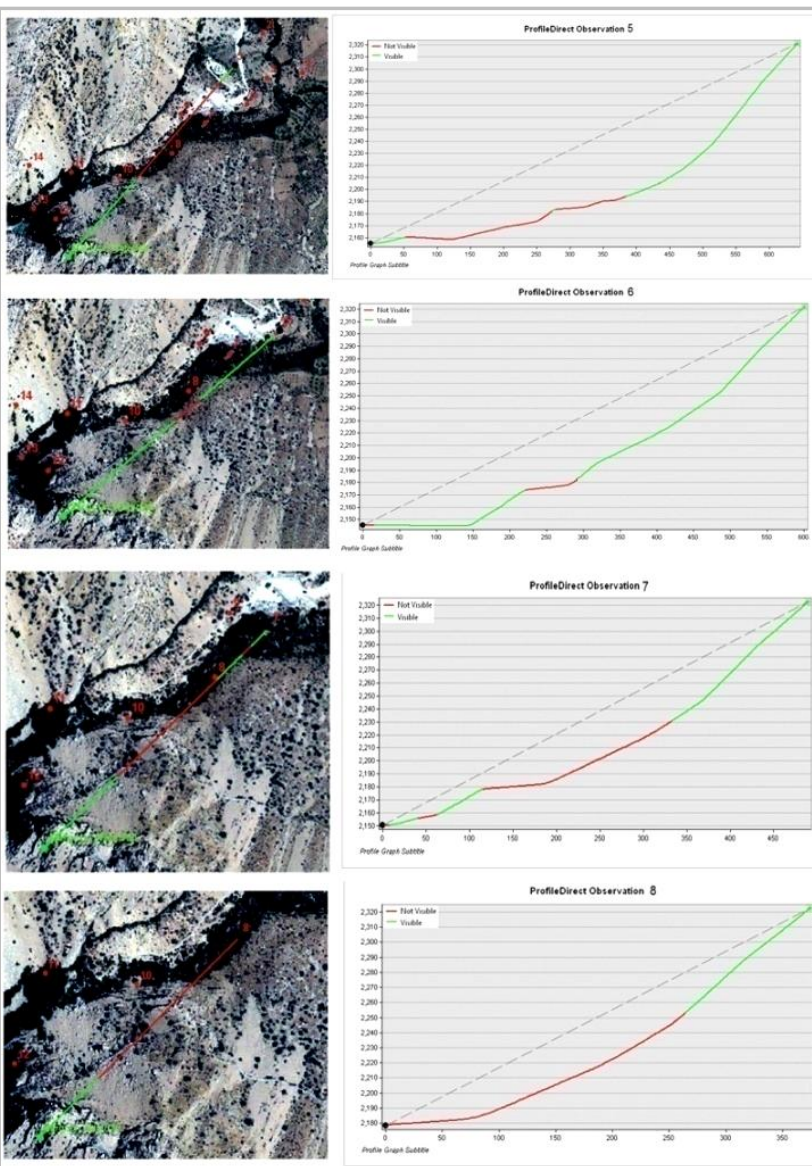

Figure 7: Position and view angle of selected point 1-8 


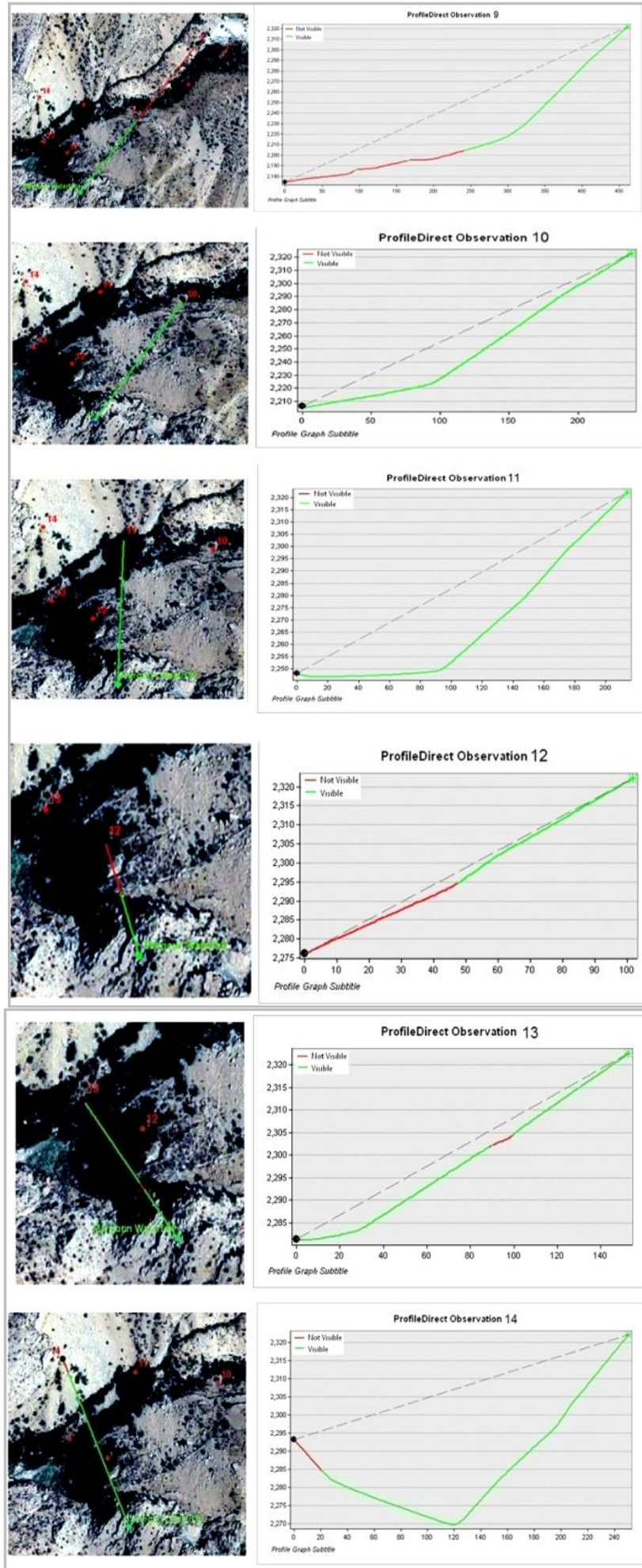

Figure 8: Position and view angle of selected point 9-14

\section{CONCLUSIONS}

Margoon waterfall protected area has ecological, cultural, social, and economic features. Nowadays, this area face many problems because of incompatible landscape design. The analysis indicate that the proposed development design in Margoon waterfall protected area do not considered by native and exotic society because of failure to adapt to the demands and needs of local communities on the one hand and the lack of visual assessment on the other hand. Therefore, we recommended designer and researchers to recognize core and buffer zones in Margoon protected area by using survey methods. This method helps the designer to identify incompatible land uses and ecological disturbances. Then proposed design should be adapted to visual need of visitors (native communities or tourists). In fact, visual and aesthetic evaluation should be considered as a separate dimension in design process.

Therefore, we recommend improving the quality of privileged landscape (point 9-14). Some parts of of this range due to the placement of the gradient were undetectable. Therefore, we recommend to plant native trees and shrubs to improve the visual quality. Extensive tourism activities such as hiking trails, forests and hiking tour of further can be development in this range. camping in this range cause some problems so we recommend transforming camping in to range point $1-4$. in ordinary landscape we recommend new patches of green spaces to create logical relationship between green patches of this site that have been disappearance due to the lack of consideration to the stainable design process in natural monuments.

\section{REFERENCES}

Behbahani, H and Razi Moftakhar, N. (2005). Sustainable Design of Sheikh Tapeh Forest Park, Urmiah. Environmental Studies Journal 37(1): 89-104.

Bell, S. (2003). Landscape, Pattern, Perception and Process. Translated from English into Persian by Carmona, M. Public places, Urban Spaces. Architectural press.

Calkins, M. (2009). Strategy use and challenges of ecological design in landscape architecture. Landscape and Urban Planning 73: 29-48.

Dicastri, F. (1996). Sustainable Development Seat. Nature and Resources Journal 7: 1-8.

Forman, R. and Godren, M. (1986). Landscape Ecology. New York: Wiley and Sons.

Mc Grigal, K. (2002). Fragstas: Spatial Pattern Analysis Program For Categorical Map. Amherest: University of Massachusets.

McGarigal, K. and McComb, W. (1995). Relation between landscape structure and breeding birds in the Oregon coast coast range. Ecological Monographs 65(2): 235260.

Selmun, P. (2008). Planning at the Landscape Scale. London: Taylor and Francis group.

Spirn, A.W. (2000). The Language of Landscape. Yale University Press. 